\title{
STANDAARDE VIR DIE MAAK VAN 'N GEMEENSKAPSDIAGNOSE
}

\author{
Marlene J Viljoen, Marie E Muller, Leana R Uys
}

\section{INLEIDING}

Die gemeenskapsverpleegkundige is ' $n$ onafhanklike praktisyn en werk as lid van 'n gesondheidspan wat saamgestel is uit ' $n$ verskeidenheid professionele gesondheidspraktisyns en ander werkers. Die rol en funksies van die hedendaagse gemeenskapsverpleegkundige is nie net meer beperk tot moeder- en babasorg en voorkoming van oordraagbare siektes nie, maar vereis dat hy/sy binne 'n spanverband, die gesondheid van die totale gemeenskap bevorder: “. . . it's a matter of focus on group health problems, present and projected, in contrast to

dividual, clinically oriented care"

choolcraft, 1984: 451)

'n Hoë gehalte gemeenskapgesondheidsverpleging vereis ' $n$ wetenskaplik-

gefundeerde benadering ten einde aan die eise van 'n hoë gehalte dienslewering te kan voorsien. 'n Gemeenskapsdiagnose stel die gemeenskapsverpleegkundige in staat om gesondheidsdienslewering op 'n wetenskaplike vlak te plaas.

Die gemeenskapsverpleegkundige benodig riglyne vir die mak van 'n gemeenskapsdiagnose. Daar is geen standaarde in hierdie verband, vanuit 'n Suid-Afrikaanse perspektief, beskikbaar nie. Daar is dus nog nooit deur kundiges besluit wat behoort werklik in hierdie gemeenskapsdiagnose ingesluit te word nie.

Die formulering van geldige standaarde vir die maak van 'n gemeenskapsdiagnose, deur die gemeenskapsverpleegkundige, is dus essensieel. Daar is ook 'n behoefte aan 'n instrument waarvolgens die gehalte van meenskapsdiagnosering bepaal kan word.

Die doel van hierdie studie is om nasionale standaarde vir die maak van 'n gemeenskaps-diagnose te formuleer en om 'n meetinstrument daarvolgens te ontwerp.

\section{LITERATUUROORSIG}

Die gemeenskapsverpleegkundige is gemoeid met 'n gemeenskapsberaming omdat die gemeenskap die omgewing is waarbinne die kliënte funksioneer en vanwaar gesondheidsdienslewering plaasvind. Die inwoners is van die gemeenskapsbronne afhanklik om gesondheidsprobleme die hoof te bied (Elkins, 1984: 48). Dit is dus belangrik dat die gemeenskapsverpleegkundige die gemeenskap ken en verstaan (Burgess, 1983 123).

'n Gemeenskapsberaming voorsien die gemeenskapsverpleegkundige van ' $n$ databasis wat benodig word vir die identifisering van gesondheidsprobleme in 'n gemeenskap ten einde sinvolle beplanning van tussentredes te kan uitvoer (Elkins, 1984:

43). Hierdie beraming vereis sekere vaardighede wat op ' $n$ logiese,

gesistematiseerde wyse uitgevoer word.

\section{UITTREKSEL}

Standaarde vir die maak van 'n gemeenskapsdiagnose is geformuleer en nasionaal gevalideer wat as riglyn deur gemeenskapsverpleegkundiges benut kan word om die gehalte van gemeenskapsdiagnosering te verbeter. Die gehalle (volledigheid van) gemeenskapsdiagnosering deur gemeenskapsverpleegkundiges is by wyse van ' $n$ retrospektiewe ouditering beoordeel. Leemtes is veral opmerklik in die samestelling van ' $n$ gesondheidsprofiel en databronne is ontoereikend deur die gemeenskapsverpleegkundiges benut. In die interpretering van die data is belangrike gesondheidsaanwysers nie in ag geneem nie en beplanningstrategie ë is onvolledig verantwoord. Dit wil voorkom asof die gemeenskapsverpleegkundige meer aandag aan data skenk wat meer geredelik beskikbaar is en wat vir die bereiking van vinnige resultate in haar/sy gemeenskapsbeplanning aangewend word.

\section{ABSTRACT}

Standards for the making of a community diagnosis were formulated and validated on a national basis. These standards can be utilised by the community health nurse to improve the quality of community

diagnoses.

The quality of community diagnosis by community health nurses, was analysed by means of a retrospective audit. Incomplete diagnosis were observed in the compilation of a community profile and data resources were inadequately utilised. Important health indicators were not taken into account during the interpretation of dat a and planning strategies were incomplete. It appears as if the community health nurse tends to pay more attention to data that is readily available or can be utilised for quick results in his/her community planning.

Die maak van 'n gemeenskapsdiagnose Die beginsels van sistematiese probleemoplossing geld ook vir die maak van 'n gemeenskapsdiagnose. Dit sluit in 'n begrip van die probleem, dataversameling en -analisering, en die maak van gevolgtrekkings (Schoolcraft, 1984: 451). Die basiese beginsels van epidemiologiese navorsing moet dus benut word (Schoolcraft, 1984: 452).

\section{Bronne wat benut kan word}

\section{a) Gemeenskapsdata}

Gemeenskapsdata lê opgesluit in byvoorbeeld sensusstatistieke, morbiditeit- en mortaliteitsyfers en demografiese data wat by die plaaslike regerings- en gesondheidsinstansies verkrygbaar is. Selfs die plaaslike hospitaa kan belangrike inligting aangaande die gesondheidsprobleme van die spesifieke gemeenskap verskaf (Burgess, 1983: 136; Elkins, 1984: 45).

b) Individuele verbruikers, familielede en betekenisvolle ander

Die individue wat die gesondheidsdienste benut, verskaf belangrike inligting vir die maak van die gemeenskapsdiagnose. Die nagaan van individuele gesondheidsrekords is 'n moontlikheid wat deur die gemeenskapsverpleegkundige ondersoek kan word (Elkins, 1984: 45).

\section{c) Gesondheidsorgverskaffers en organisasies}

Die benutting van byvoorbeeld rekords van geneeshere, hospitale en gemeenskapsentra tydens die dataversamelingsproses, is belangrik. Spesifieke siekte-organisasies, soos die kankervereniging, ensovoorts, is ook belangrike inligtingsbronne (Burgess, 1983: 136; Elkins, 1984: 46).

d) Individue en groepe in die gemeenskap Die versameling van inligting aangaande sekere groepe in 'n gemeenskap is soms problematies. Dit noodsaak ook onderhoudvoering met groeplede of belangegroepe, of die gebruik van vraelyste. Statistieke is ook soms verkrygbaar van nasionale-, streeks- en gemeenskapsbelangegroepe (Elkins, 1984: 45).

\section{e) Relevante wetenskaplike literatuur, navorsing en statistieke}

Die benutting van wetenskaplike literatuur, navorsing en statistieke deur die gemeenskapsverpleegkundige, is ' $n$ vaardigheid wat nie genoeg beklemtoon kan word nie.

Van die bronne waar hierdie data verkry kan word is ondermeer die plaaslike biblioteek, gesondheidspraktisyns en professionele belangegroepe. Die verpleegkundige moet egter die vermoë hê om te kan onderskei tussen data wat slegs op sekere gemeenskappe betrekking het (Burgess, 1983 136; Elkins, 1984: 45).

\section{Die beramingsproses}

Die beramingsproses vir die maak van 'n gemeenskapsdiagnose bestaan uit opeenvolgende stappe wat vervolgens kortliks bespreek word.

\section{a) Identifiseer die populasie}

Volgens Schoolcraft (1984: 451) is die eerste stap die identifisering van die populasie, met die vraag: "Who is included in the com- 
munity?" Dit sluit in die versameling van inligting aangaande die teikengroep se sosioekonomiese en demografiese kenmerke. asook die etno-kulturele faktore, waardes en ideale. ' $n$ Beraming van die groep (gemeenskap) se doel en strewe sal spesifieke behoeftes soos ondersteuning, deelname, sosialisering, produksie en verspreiding van goedere, insluit.

In hierdie stap moet die gemeenskapsverpleegkundige dus die teikenpopulasie (ouderdoms- of belangegroep) identifiseer en omskryf. Die rede vir die selektering van hierdie teikenpopulasie moet duidelik gemeld word (Burgess, 1983a: 126; Sullivan, 1984: 73). Burgess (1983: 127) beklemtoon ook die belang van ' $n$ historiese oorsig van die gemeenskap.

Spesifieke inligting aangaande die populasie sluit nie net inligting aangaande die ouderdom, geslag en digtheid van die gemeenskap in nie, maar ook kulturele, opvoedkundige en religieuse data (Elkins, 1984: 49).

\section{b) Stel 'n gemeenskapsprofiel saam}

In die samestelling van 'n gemeenskapsprofiel is outeurs dit eens dat die geografiese grense en die omgewingstoestande duidelik omskryf moet word. Die fisiese kenmerke van die gemeenskap, soos die grense, geografie, klimaat en omgewingstoestande behoort volgens Burgess (1983: 127) eerste omskryf te word.

Demografiese inligting soos die ouderdom, geslag, geboone- en sterftesyfers van die gemeenskap is essensiele basiese inligting vir die maak van 'n gemeenskapsdiagnose (Braden, 1984: 281-283; Burgess, 1983: 127; Schoolcraft, 1984: 452; Young, 1982: 68)

Omgewingstoestande soos die klimaat en die implikasies daarvan vir gesondheid, die tipes besoedeling, waterbronne en sanitasiemetodes, is ook basiese data wat versamel moet word (Elkins, 1984: 49; Young, 1982: 67-69).

Behuisingsdata sluit inligting aangaande die aard, tipe en standaard van behuising in wat 'n moontlike invloed op die gesondheidsprofiel van die gemeenskap kan hê (Elkins, 1984: 49)

Besigheids- en industriële ontwikkelinge, asook die opvoedkundige stelsels, welsynsen vrywillige dienste in die gemeenskap, moet ontleed word (Braden, 1984: 283; Elkins, 1984: 49). Braden (1984: 293) beklemtoon ook die beraming van ontspanningsfasiliteite.

Die politieke strukture, formeel en informeel, moet beskryf word. Die politieke figure en ander sleutelpersone in die gemeenskap moet geïdentifiseer word (Elkins, 1984: 50; Leahy, 1982: 97; Young, 1982: 68).

Die kommunikasie- en vervoerstelsels moet goed ontleed word, insluitende die noodbeplanningstrukture (Braden, 1984: 293; Elkins, 1984: 51; Young, 1982: 68-69).

Die sosio-ekonomiese faktore, soos die finansiële bronne in die gemeenskap, die finansiële status van die inwoners en belastingstelsel moet, ondermeer, beskryf word (Burgess, 1983: 130; Leahy, 1982: 101).

'n Intensiewe beraming van die gemeenskap se gesondheidsdiensstelsels, beide openbare- en privaatdienste, is belangrik. Dit sluit die voorsiening van basiese dienste soos die beskerming van water- en voedselvoorrade, primêre gesondheidsdienste, hospitalisasie, asook die aard en hoeveelheid professionele en nieprofessionele gesondheidsdienswerkers in (Elkins, 1984: 51).

Braden (1984: 283) beklemtoon die versameling van noodsaaklike (vital) inligting wat verband hou met die gesondheidsprofiel. Die samestelling van 'n gesondheidsprofiel vereis 'n ontleding van gesondheidstatistieke in die gemeenskap. Morbiditeit- en mortaliteitsyfers, algemene gesondheidsprobleme, asook die mees algemene faktore wat die gesondheid van die gemeenskap beïnvloed, moet ontleed word. Gesondheidsverwante praktyke, soos dieet, rook, oefening, alkoholen dwelmverbruik, is ook belangrike inligting vir die samestelling van 'n gemeenskapsprofiel (Braden, 1984: 293; Elkins, 1984: 52; Sullivan, 1984: 84).

Terwille van 'n logiese samestelling van 'n gemeenskapsprofiel, beveel Burgess (1983: 129) aan dat die gemeenskapsverpleegkundige eers die fisiese kenmerke van die gemeenskap moet beskryf waamá die mense van die gemeenskap beskryf word.

\section{c) Analiseer die gesondheidsprobleme}

'n Kort historiese oorsig van die gemcenskap word deur Schoolcraft (1984: 452) beklemtoon. Identifisering van gesondheidsprobleme, veral oor die afgelope tien jaar, insluitende risiko-groepe, is kardinaal vir 'n goeie gemeenskapsdiagnose. Faktore wat moontlik aanleiding kan gee tot die spesifieke gesondheidsprobleme moet ontleed word. Dit sluit omgewings- en beroepsgesondheidsfaktore in. Die gesondheidsindikators, soos mortaliteit - en morbiditeitsyfers moet nougeset ontleed word (Schoolcraft, 1984: 452).

\section{d) Interpreteer die data}

Nadat al die inligting aangaande die gemeenskap versamel is, kan die gemeenskapsverpleegkundige begin om die data te interpreteer. Burgess (1983: 138) beveel 'n sistematiese interpretasie aangaande die volgende aan:

- die algemene sterkpunte (strengths);

- die hoof probleme waarmee die gemeenskap te kampe het

- die hoof gesondheidsprobleme;

- huidige en voorgestelde gemeenskapsaksies vir die oplossing van die probleme.

Sullivan (1984: 81) is van mening dat die gemeenskapsverpleegkundige moet besluit of hierdie gemeenskap eiesoortige gesondheidsprobleme het. Hierdie interpretasie is ook afhanklik van die eiesoortige samestelling, gewoontes en tradisionele praktyke van die gemeenskap.

e) Analiseer die benaderings wat deur die gemeenskap gevolg is om probleme in die verlede op te los

Schoolcraft (1984: 452) beklemtoon die analisering van benaderings wat deur die gemeenskap in die verlede gevolg is om probleme op te los. Die aard en omvang van die benaderings, asook die effektiwiteit daarvan, moet ondersoek word.

Die gemeenskapsverpleegkundige moet dus klem lê op die primêre voorkomingstrategieë wat in die verlede aangewend was, asook die tersiêre voorkomingstrategieë om langtermyn wanfunksionering te voorkom. Schoolcraft (1984: 452) beklemtoon ook 'n opname van gesondheidsbronne wat in die gemeenskap vir risiko-groepe beskikbaar is.

\section{f) Formuleer die gemeenskapsdiagnose}

Nadat al die inligting versamel en ontleed is moet ' $n$ gemeenskapsdiagnose geformuleer word. Die diagnosering van die gemeenskap se gesondheidstatus en die implikasies van hierdie diagnose is dus tersaaklik (Burgess, 1983: 139; Schoolcraft, 1984: 452). 'n

Logiese en sistematiese uiteensetting van die data sal die gemeenskapsdiagnosering vergemaklik.

\section{g) Formuleer die doelstellings aard en} intensiteit van verandering wat beoog word In hierdie stap is dit belangrik om volgens die gesondheidsbehoeftes en -probleme van die gemeenskap 'n plan van aksie saam te stel waarin die lang- en kortermyndoelstellings uitgespel word. Die bepaling van prioriteite, volgens die gemeenskap se vermoens, is 'n vanselfsprekende aspek van hierdie stap (Leahy, 1982: 107-109; Sullivan, 1984: 85). Leahy (1982: 109) beklemtoon ook gemeenskapsbetrokkenheid in hierdie verband.

h) Bepaal die gemeenskap se vermoens, koste en beskikbaarheid van bronne om die doelstellings te bereik

Alvorens 'n plan van aksie opgestel kan word moet die gemeenskapsverpleegkundige die nodige fasiliteite, bronne, finansies en vermoëns van die gemeenskap beoordeel sodat realistiese, sinvolle doelbereiking moontlik is (Tinkham, 1977: 227).

Die maak van 'n gemeenskapsdiagnose vereis dus 'n logiese, sistematiese proses van beraming, interpretering, en beplanning vir tussentrede. Hierdie beramingsproses sluit dataversameling aangaande die volgende in:

- die fisiese kenmerke van die gemeenskap om die uniekheid van die gemeenskap te beskryf;

- data aangaande die mense in die gemeenskap;

- kennis betreffende die omgewing, wat behuising, lug, water, veiligheid en ander gesondheidsverwante faktore, insluit;

- die kommunikasiestelsel;

- statistiese inligting aangaande die gesondheids- en siektepatrone van die gemeenskap;

- data aangaande gesondheidsverwante fasiliteite, bronne en personeel;

- kennis oor die gemeenskapgesondheidsdienste en -programme in die gemeenskap (Tinkham, 1977: 203)

Indien die gemeenskapsverpleegkundige al die voorafgaande aspekte ontleed en interpreteer kan 'n gemeenskapsdiagnose van hoogstaande gehalte gemaak word.

Standaarde vorm die basis van gehalteversekering. Drie tipes standaarde word onderskei, naamlik struktuur-, proses- en produkstandaarde. Werklike praktykvoering word met hierdie gestelde standaarde vergelyk ten einde die gehalte van dienslewering te beoordeel. 


\section{DEFINIËRING VAN TERME}

\section{Standaard}

'n Standaard is 'n beskrywende verklaring van die verwagte vlak van werkverrigting waarteen die gehalte van struktuur-, prosesen produkstandaarde beoordeel kan word.

\section{Kriteria}

Kriteria is daardie veranderlikes wat uit standaarde geselekteer word as die maatstaf waarteen gehalte gemeet word.

\section{Gemeenskap}

'n Gemeenskap is 'n plek, dit wil sê 'n geografiese entiteit. Dit het 'n spesifieke omgewing, wonings, nywerhede, handels- en ontspanningsgeriewe en 'n vervoerstelsel. Die gemeenskap is ook 'n maatskaplike stelsel en bevat talle substelsels en ' $n$ ingewikkelde netwerk wedersydse verhoudings is tussen die substelsels daargestel om die belangrikste funksies van die besondere maatskaplike stelsel te verrig. ' $n$ Gemeenskap is ook 'n versameling mense wat ' $n$ bepaalde kultuur, norme, waardes en houdings handhaaf. So 'n ersameling mense kan bestaan uit ' $n$ verskeidenheid etniese, godsdienstige, sosioekonomiese en opvoedkundige groepe. 'n Gemeenskap verwys dus na mense en die verhoudings wat tussen hulle ontstaan wanneer hulle gemeenskaplike bronne, agente, instellings en 'n fisiese omgewing benut.

\section{Gemeenskapsberaming}

'n Gemeenskapsberaming verwys na die proses waarvolgens verpleegkundiges die omvang van gesondheidsprobleme in ' $n$ geselekteerde gemeenskap bepaal en die beskikbare hulpbronne identifiseer.

\section{Gemeenskapsdiagnose}

'n Gemeenskapsdiagnose is die opsommende verklaring of gevolgtrekking wat vanuit 'n gemeenskapsberaming gemaak word.

\section{ehalte}

Gehalte verwys na die kenmerke van voortreflikheid en impliseer die konformering aan voorafbepaalde standaarde.

\section{Gemeenskapsverpleegkundige}

'n Gemeenskapsverpleegkundige is ' $n$ geregistreerde verpleegkundige wat by die Suid-Afrikaanse Raad op Verpleging in Gemeenskapsverpleegkunde geregistreer is en in die gemeenskap praktiseer.

\section{NAVORSINGSMETODE}

\section{Navorsingsontwerp}

Ten einde teoretiese geldigheid aan die formulering van standaarde vir die maak van 'n gemeenskapsdiagnose te verseker, is 'n grondige literatuurstudie in hierdie verband onderneem. 'n Beskrywende instrumentele benadering is gevolg waardeur die domeinveranderlikes sistematies verken, beskryf en gevalideer is. Die gehalte van gemeenskapsdiagnosering is vervolgens by

\section{Populasie en steekproef}

Die teikenpopulasie vir die formulering van standaarde vir die maak van 'n gemeenskapsdiagnose, sluit alle gemeenskapsverpleegkundiges in Suid-Afrika in. Doelgerigte en oordeelkundige steekproefneming is vanuit die teikenpopulasie in beide die ontwikkelings- en kwantifiseringsfases vir die validering van die standaarde gebruik. Die Nasionale Genootskap van Gemeenskapsverpleegkundiges van Suid-Afrika (NGGV) is as forum gebruik waarvolgens die kundiges op nege streeksvlakke gekoordineer is.

\section{(a) Ontwikkelingsfase}

Lynn (1983: 383) beveel 'n minimum van drie domeinkundiges vir die validering van standaarde in die ontwikkelingstadium aan. Domeinkundigheid is gebaseer op die steek proefpersone se akademiese- en praktykervaring in gemeenskapsverpleegkunde.

Die vier-en-twintig nasionale bestuurslede van die NGGV is in hierdie fase betrek. 'n Bestuurslid uit elke streek is as kontakpersoon en sameroepster geselekteer wat domeinkudiges in haar/sy streek doelgerig geselekteer het om aan portuurgroepbesprekings deel te neem. Groepe van ses tot agt domeinkundiges is in elk van die nege streke saamgestel.

\section{(b) Kwantifiseringsfase}

'n Minimum van vyf domeinkundiges word deur Lynn (1986: 383) aanbeveel ten einde 'n toereikende vlak van kontrole oor lukrake besluitneming/saamstem (chance agreement) te beoefen. Agt domeinkundiges is deur die navorsers oordeelkundig vir hierdie fase van die studie vanuit die vier provinsies geselekteer.

Vir die beoordeling van die gehalte van gemeenskapsdiagnosering, is alle owerhede wat betrokke is by gemeenskapsdienste gekontak en gevra om alle gemeenskappe, waarvan gemeenskapsdiagnoses opgestel is, te identifiseer. Die gemeenskapsverpleegkundiges in al hierdie gemeenskappe is skriftelik versoek om aan die ondersoek deel te neem. Niemand het geweier nie. Alle gemeenskapsdiagnoses wat opgespoor kon word is dus ingesluit.

Die finale steekproef het uit beide stedelike en plattelandse gemeenskapsdiagnoses in Natal $(\mathbf{N}=9)$, die Kaapprovinsie $(\mathbf{N}=9)$ en die Oranje-Vrystaat $(\mathbf{N}=$ 4) bestaan (geen terugvoering is van Transvaal ontvang nie). ' $n$ Totaal van 22 gemeenskapsdiagnoses wat deur die steekproefpersone uitgevoer is, is in die studie betrek.

Toestemmings is skriftelik van die betrokke owerhede verkry.

\section{Navorsingstegniek}

Die formulering van standaarde bestaan uit twee fases, te wete die ontwikkelings- en kwantifiseringsfases wat elk kortliks bespreek sal word.

\section{(a) Ontwikkelingsfase}

Die eerste stap in die formulering van standaarde, naamlik die ontwikkelingsfase, behels die onderneming van 'n omvattende literatuurstudie oor die bestaande praktyk waartydens die domeinveranderlikes geidentifiseer en beskryf word (Mason, 1975: 5). Die navorsers het van 'n wye reeks bronne, hoofsaaklik Amerikaanse- en Europese literatuur, gebruik gemaak.

Toepaslik items (konstrukveranderlikes) is vervolgens deur 'n kennergroep gegenereer.

Kognitiewe analisering van die teoretiese konsepte en die logiese sistematisering van hierdie konsepte is uitgevoer en is in die vorm van konsepstandaarde in albei landstale opgestel en vir portuurgroepbeoordeling voorberei.

Die doel en omvang van hierdie navorsingsprojek is by ' $n$ bestuursvergadering van die NGGV op 30 April 1988 deur die voorsitter, (wat ook as navorser by die studie betrokke is), bekend gemaak. 'n Gedesentraliseerde benadering is gevolg waarin 'n bestuurslid, wat as kontakpersoon en sameroepster in elke streek funksioneer, afsonderlike portuurgroepbesprekings gereël het.

Agtergrondinligting oor die aard van die navorsing, asook instruksies ter voorbereiding van die standaarde vir die bespreking, is skriftelik saam met die konsepstandaarde aan elke steekproefpersoon versend. Die navorser het as inligtingsbron opgetree en telefoonnommers is aan die streekskontakpersone voorsien indien verdere inligting benodig sou word.

Die doel van die portuurgroepbeoordeling was om die standaarde te verfyn, verder te ontwikkel of uit te brei ten einde die inhoudsgeldigheid van die standaarde te versterk. 'n Kort debat is oor elke standaard gevoer en die groep se algemene konsensus is verkry.

Aanbevelings is deur die kontakpersone vanuit die streke na die navorser terugversend wat die nodige veranderinge aangebring het. Die standaarde is vervolgens vir die kwantifiseringsfase voorberei.

\section{(b) Kwantifiseringsfase}

Lynn (1986: 383) propageer vervolgens 'n kwantifiseringsfase waartydens die statistiese geldigheid van die standaarde verreken word. 'n Vierpunt-ordinale Liken graderingskaal is soos volg vir elke standaard aangebring:

1 irrelevant, glad nie toepaslik

2 onduidelik/toepassing bevraagteken

3 toepaslik maar benodig herformulering

4 volledig, duidelik, goed-geformuleer en hoogs toepaslik.

Hierdie standaarde is aan agt steekproefpersone vir finale validering versend. Agtergrondinligting oor die aard van die navorsingstudie asook instruksies vir die gradering (validering) van die standaarde is ingesluit. Telefoniese kommunikasie met die steekproefpersone is, waar moontlik, vooraf gevoer

'n Gestruktureerde ouditeringsinstrument is vervolgens ontwerp, gebaseer op standaarde en kriteria wat geformuleer en nasionaal gevalideer is. Graderings van ja, nee en nie-van-toepassing, asook nooit, soms en altyd is gebruik.

Die gemeenskaps-diagnosering is voorts by wyse van retrospektiewe ouditering van rekords beoordeel. Die gemeenskapsdiagnoses is deur drie 
veldwerkers, wat elk oor die bykomende kwalifikasie in Gemeenskapsverpleegkunde beskik, gemeet en beoordeel.

\section{Loodsstudie}

Vyf gemeenskapsdiagnoses is deur 'n navorser in Natal beoordeel waarna die ouditeringsinstrument vir finale evaluering voorberei is.

\section{Geldigheid van die standaarde en evalueringsinstrument}

Inhoudsgeldigheid van die standaarde is deur die literatuur en deur domeinkundiges bevestig. Statistiese inhoudsgeldigheid van die standaarde is gedurende die kwantifiseringstadium by wyse van ' $n$ inhoudsgeldigheidsindeks verreken. 'n Item (standaard) wat 'n gemiddelde gradering van drie tot vier behaal, word as geldig aanvaar. Konstrukgeldigheid is nie in hierdie studie bepaal nie.

Die gevalideerde standaarde en kriteria verleen inhoudsgeldigheid aan die instrument.

\section{Betroubaarheid van die standaarde en instrument}

Betroubaarheid van die valideringsresultate is soos volg deur die navorsers gekontroleer:

a) 'n Gestruktureerde twee-fase prosedure vir die validering van die standaarde is gebruik.

b) Gestruktureerde en duidelike instruksies is skriftelik en/of mondelings deur die navorsers aan die steekproefpersone in albei die valideringstadia van die standaarde gegee.

c) Tydens die debatering van die standaarde gedurende die ontwikkelingsfase is gepoog om ewekansige geleentheid aan elke steekproefpersoon te gee waarvolgens opinies gelug en aanbevelings gemaak kon word.

d) ' $n$ Verteenwoordigende en relatiewe groot groep kundiges (agt) is geselekteer om die standaarde nasionaal, vanuit al vier die provinsies, te valideer.

Weens die klein steekproefgrootte $(\mathrm{N}=$ 22) betreffende die evaluering van die gehalte gemeenskapsdiagnosering deur gemeenskapsverpleegkundiges, is die statistiese verrekening van die instrument se betroubaarheid, asook interwaarnemerbetroubaarheid, bemoeilik en derhalwe nie uitgevoer nie.

\section{RESULTATE}

Agt standaarde, met verwante kriteria, is geformuleer. Tydens die $\mathrm{kwantifiseringsfase}$ is konsensus deur al die kundiges bereik. $\mathrm{Al}$ die standaarde en kriteria het ' $n$ inhoudsgeldigheidsindeks van 4 behaal. Die volgende standaarde is geformuleer:

\section{1. 'n Gemeenskapsprofiel word saamgestel}

1.1 'n Oorsigtelike beskrywing van die gemeenskap se geskiedenis word gegee;

Die rede vir die seleksie van die gemeenskap is verklaar; Die gemeenskapsberaming is gedoen en die beramingsinstrument inkorporeer die
1.3.1.1.

1.3.1.2

volgende:

Die fisiese kenmerke van die

gemeenskap:

Die geografiese grense

Die omgewingstoestande:

geografie

stedelik/plattelands

klimaat

waterbronne

teenwoordigheid van natuurlike

bronne (bome, gras, riviere,

spruite)

1.3.1.3 Omgewingsgesondheidsgevare:

besoedeling (tipe)

beroepsgesondheidsgevare

gesondheidsgevare in buurte

1.3.1.4 Behuising:

toestand

hoeveelheid inwoners

hoeveelheid ekonomiese en sub-

ekonomiese behuising

1.3.1.5 Besigheids- en nywerheidsinstellings

1.3.2 Inligting betreffende die gemeenskap se bevolking:

1.3.2.1 Sosiografiese kenmerke van die bevolking:

groeitendense

digtheid

ouderdomsverspreiding

geslagsverspreiding

huwelikstatus

gesinstatus

oorheersende ras/etniese groepe

opvoedkundige vlak (mediaan

jare voltooi)

sosio-ekonomiese status

indiensneming/werkloosheid

syfers

trekarbeid

oorheersende religieuse groep

geboorte-, sterfte-, fertiliteit-,

morbiditeit- en mortaliteitsyfers

1.3.2.2 Gesondheidstatus:

* vorige benutting van

gesondheidsfasiliteite

* houdings teenoor gesondheid en

behoefte aan gesondheidsorg

* individuele verantwoordelikheid vir persoonlike gesondheidsgewoontes vir die bevordering van gesondheid en veilige omgewing

1.3.2.3 Reaksie van verbruikers op opvoedkundige gesondheids programme

1.3.2.4 Gesondheidsverwante praktyke: dieet

oefening

rook

alkoholverbruik

dwelmverbruik

1.3.2.5 Gesondheidsverwante kenmerke: groepe wat die gemeenskap vorm (kern en uitgebreide gesinne, sosiale groepe, ensovoorts)

kulturele- en gewoontepraktyke, oortuigings en houdings

1.3.2.6 Siekte-patrone en gesondheidsprobleme van die gemeenskap: voorkoms in die gemeenskap (nuwe gevalle of insidensiesyfers)

* huidig teenwoordig in die gemeenskap (aanwesig/ heersend)

oorsake van sterftes in die gemeenskap (sterfte/ mortaliteitsyfers)

toename in die gemeenskap of hoër as in ander areas

1.3.2.8

1.3 .3

1.3.3.1 Gesondheidsbehoeftes deur die gemeenskap geïdentifiseer Sosiale patologie

Inligting betreffende die infrastruktuur van die gemeenskap:

Politieke stelsel:

tipe

magstruktuur: formeel/

informeel

besluitnemingsproses

sterk- en swakpunte

(strengths/weaknesses)

betreffende die leierskap en mag

1.3.3.2 Ekonomiese stelsel:

belastingbasis

tipes nywerhede en

ontwikkelende projekte

toewysing van fondse in die

gemeenskap

gemeenskap se sterk- en

swakpunte betreffende

finansiële bronne

1.3.3.3 Opvoedkundige stelsel:

formeel: primêre-, sekondêre-

en tersiêre fasiliteite

informeel

1.3.3.4 Kommunikasiestelsel:

informeel

massa media: dekking van gesondheidsaspekte en invloed op gesondheidsgedrag sleutel-informante

posdienste

nood- en rampkommunikasie

Vervoerstelsel:

private

openbare

paaie: toeganklikheid

beskikbaarheid

1.3.3.6 Welsynsdienste

1.3.3.7 Ontspanningsfasiliteite en

-programme

1.3.3.8 Veiligheidsprogramme

(brandbeskerming, polisie

beskerming)

1.3.3.9 Buurtwagdienste

(kruidenierware store,

inkopiesentra, kerke)

1.3.4 Inligting betreffende die gesondheidsorgstelsel:

1.3.4.1 Persoonlike gesondheidsdienste

1.3.4.1.1 Kenmerke van sorg en dienste verskaf (frekwensie, beskikbaarheid, toeganklikheid, vlakke van gesondheidsorg,

finansiëring):

provinsiaal

streeksbestuur

plaaslike owerheid

privaat

verwysingsbronne

1.3.4.1.2 Resultate van behandeling of dienste gelewer

1.3.4.2 Nie-persoonlik:

vektorbeheer

afvalverwydering

sanitasie

beskerming van water-

voorsiening/voorrade

beskerming van voedselbrot.ne 

Gesondheidspersoneel: professioneel

leke werkers

1.3.4.4 Welsynsgesondheidsdienste en -agente

1.3.4.5 Gemeenskapgesondheidsbronne: gemeenskap- en verbruikerbetrokkenheid in gesondheidsbeplanning

* selfhelpprogramme

2. Die beskikbare data-bronne word vir dataversameling gebruik, soos:

2.1 Individuele verbruikers

2.2 Gesin en betekenisvolle ander

2.3 Gesondheidsdiensvoorsieners

2.4 Individue en groepe in die gemeenskap

2.5 Relevante wetenskaplike literatuur

$2.6 \quad$ Relevante navorsingstudies

2.7 Relevante wetenskaplike statistieke

3. Die metodes vir die verkryging van data is in ooreenstemming met die beskikbare data-bronne, die tipe gemeenskap wat bestudeer word, die beskikbare analiseringstyd asook die hoeveelheid persone wat by die analise betrokke is

\section{Die data word geïnterpreteer:}

4.1 Gesondheidsprobleme word geanaliseer, geidentifiseer en risikogroepe (teikenpopulasie) word gekategoriseer deur die toepaslike gesondheidsaanwysers toe te pas. Die betekenisvolheid en vlak van gemeenskapsbewustheid is verklaar;

4.2 Onderskeid word gemaak tussen probleme geidentifiseer deur professionele personeel versus daardie deur die gemeenskap geidentifiseer;

4.3 Risikogroepe binne die populasie betreffende siektes, ongeskiktheid of premature sterftes word geidentifiseer;

4.4 Risikofaktore verwant tot die geïdentifiseerde probleme word ontleed en geklassifiseer:

4.4.1 Daardie wat nie gemaklik veranderbaar is nie:

* demografiese kenmerke: geslag ouderdom, ras, huwelikstatus, sosio-ekonomiese status

4.4.2 Daardie wat moontlik/of nie moontlik is om te verander nie: oorerflike/biologiese kenmerke soos genetiese karaktertrekke, fisieke toestande soos obesiteit, hipertensie en ander siekteprosesse, ensovoorts;

4.4.3 Daardie wat meer veranderbaar is:

4.4.3.1 Omgewingsblootstellings:

* fisiese aspekte soos besoedeling. behuising, geraas, toksiese substanse

* psigososiale aspekte soos hoogs kompeterende werksomstandighede, sosiale isolasie, ander vorms van psigologiese stres
4.5 .1

4.5 .2

4.5 .3

4.5.4

Gedragskenmerke soos patrone van voedselverbruik, rook, alkohol en ander dwelms, oefening, werksgewoontes, ensovoorts

Die toepaslike gesondheidsaanwysers word op die risikogroepe toegepas:

Morbiditeit- en mortaliteitsyfers Ongeskiktheidsdae (disability)

Indekse van voedingstatus

Metings betreffende sosiale bevolkingsfaktore (insluitende rykdom) soos kriminele statistieke, werkloosheidstatistieke, armoede, depressie insluitende selfmoord, dwelmen alkoholmisbruik, ander geestesongesteldhede, stresverwante siektes, swak dieetpatrone, ensovoorts.

5. Benaderings van voorkoming en hantering van gesondheidsprobleme in die verlede word hersien en ontleed

\section{6. 'n Gemeenskapsdiagnose word} geformuleer en sluit die gesondheidstatus van die gemeenskap en die implikasies van die diagnose in

7. Die aard en hoeveelheid verandering in die gesondheidsprobleem oor 'n gegewe tyd word verklaar

8. Die vermoëns, koste en beskikbaarheid van bronne om gesondheidsprobleme te verminder en te hanteer word bepaal.

\section{RESULTATE BETREFFENDE DIE VAN GEHALTE GEMEENSKAPSDIAGNOSES}

\section{Gemeenskapsprofiel}

In die samestelling van 'n gemeenskapsprofiel blyk sekere prioriteitareas meer volledig deur die steekproefpersone beraam te word. ' $n$ Hö̈ gehalte beraming is hier veral ten opsigte van die omskrywing van die fisiese grense en sekere aspekte betreffende die omgewingstoestande uitgevoer. Leemtes is veral opmerklik in die beraming van omgewingsgesondheidsrisiko's, die tipes besoedeling en beroepsrisiko's. Sekere aspekte betreffende die behuising, soos die tipes, die fisiese toestand van die behuising, asook die water-fasiliteite, is redelik volledig deur die steekproefpersone ontleed. Die beraming van besigheids- en nywerheidsinstellings was egter deur die meerderheid steekproefpersone onvolledig beraam.

\section{a) Inligting betreffende die populasie} In hierdie afdeling is sekere sosiografiese kenmerke deurdie steekproefpersone as prioriteite redelik volledig beraam. Belangrike aspekte, soos werkverskaffing en werkloosheid, is egter deur die meeste steekproefpersone onvolledig beskryf. Die gesondheidsonderrigprogramme is onvolledig ontleed en die gesondheidsverwante praktyke is ook oor die algemeen swak beoordeel. Die gesondheidstatus van die gemeenskap, veral betreffende hul kennis van fasiliteite, houdings, insidensiesyfers en heersende siektepatrone, is ontoereikend deur die steekproefpersone beraam en beskryf. Selfs die morbiditeit - en mortaliteitsyfers behoort deur meer steekproefpersone volledig ontleed te word. Die gehalte van beramings betreffende gesondheidsprobleme en behoeftes is ontoereikend.

b) Inligting betreffende die infrastruktuur In hierdie afdeling is die beramings betreffende die politieke- en ekonomiese stelsels onvolledig, terwyl die opvoedkundige stelsel meer volledig beraam word. 'n Ontleding van die kommunikasie- en vervoerstelsels toon ook leemtes, veral betreffende die media en die toeganklikheid van die paaie.

Beramingsdata betreffende ontspanningsfasiliteite en veiligheidsmaatreëls toon 'n hoër gehalte wat deur vyftien $(\mathrm{N}=22)$ steekproefpersone onderskeidelik volledig ingesamel is.

\section{c) Gesondheidsdienste}

Inligting betreffende die gemeenskap se gesondheidsdienste is oor die algemeen onvolledig versamel. Slegs sekere aspekte in die nie-persoonlike dienste is volledig beraam naamlik sanitasie, afvalverwydering en vektor/pesbeheer.

\section{Benutting van databronne}

Beskikbare databronne is oor die algemeen ontoereikend deur die steekproefpersone benut. Gesondheidsorgvoorsieners blyk die vernaamste bron te wees wat deur die steekproefpersone benut is. Ander beskikbare bronne is ontoereikend benut wat die gehalte van die gemeenskapsdiagnosering dus benadeel.

\section{Metodes van dataversameling}

Die metodes van dataversameling toon swak ooreenstemming met die beskikbare databronne, die tyd vir analisering en die hoeveelheid mense wat by die gemeenskapsdiagnosering betrokke is. Slegs enkele steekproefpersone benut altyd 'n sistematiese metode van dataversameling.

\section{Interpretering van data}

In die interpretering van data is daar ontoereikend aan hierdie standaard voldoen. Gesondheidsprobleme is altyd deur slegs vyf steekproefpersone $(\mathrm{N}=22$ ) geidentifiseer. Die identifisering van risiko's in die gemeenskap, wat ' $n$ integrale deel van 'n gemeenskapsdiagnose behoort te vorm, is onvolledig uitgevoer. Toepaslike gesondheidsaanwysers, waarsonder die gemeenskapsverpleegkundige nie 'n hoë gehalte gemeenskapsdiagnose kan maak nie, is ook ontoereikend benut.

\section{Beplanningstrategieë}

'n Gemeenskapsdiagnose behoort sekere beplanningstrategieë vir die gemeenskapsverpleegkundige in te sluit. In hierdie kategorie is metodes, wat deur die gemeenskap in die verlede aangewend is om probleme te voorkom, ontoereikend ontleed. Die werklike maak van die gemeenskapsdiagnose, waarin die implikasies van die diagnose uitgelig word, is deur slegs sestien $(\mathrm{N}=22)$ steekproefpersone soms uitgevoer, terwyl die doelstellings vir 
verandering nie die nodige aandag geniet het nie. Die gehalte van hierdie afdeling van die gemeenskapsdiagnosering is dus nie na wense nie.

\section{GEVOLGTREKKINGS EN AANBEVELINGS}

Agt standaarde vir die maak van 'n gemeenskapsdiagnose is geformuleer en gevalideer. Hierdie standaarde behoort as riglyne gebruik te word ten einde die gehalte gemeenskapsdiagnosering deur

gemeenskapsverpleegkundiges te verbeter.

Die gehalte van gemeenskapsdiagnosering deur die gemeenskapsverpleegkundige toon leemtes, veral betreffende die samestelling van 'n gesondheidsprofiel, die identifisering van gesondheidsrisiko's, 'n ontleding van die gemeenskap se gesondheidstatus en infrastruktuur.

In die interpretering van die data is belangrike gesondheidsaanwysers nie in ag geneem nie. Beplanningstrategieë is nie deur die steekproefpersone doeltreffend beskryf nie.

Data wat maklik beskikbaar is en wat tot direkte of vinnige resultate tydens beplanning lei is wel deur die gemeenskapsverpleegkundige in die beraming en samestelling van 'n gemeenskapsdiagnose gebruik.

Die volgende aanbevelings word gemaak: a) Die benutting van die standaarde as ' $n$ selfevalueringsinstrument deur gemeenskapsverpleegkundiges ten einde die gehalte van gemeenskapsdiagnosering te verbeter.

b) Die publisering van die standaarde deur die Suid-Afrikaanse Verpleegstersvereniging.

c) Die ontwerp, implementering en evaluering van 'n personeelontwikkelingsprogram aan gemeenskapsverpleegkundiges oor gemeenskapsdiagnosering.

d) Die standaardisering van die ouditeringsinstrument.

\section{SLOTOPMERKINGS}

Standaarde vorm die hoeksteen van 'n hoë gehalte van dienslewering en behoort aan die gemeenskapsverpleegkundiges die nodige riglyne in hierdie verband te verskaf.

Die herstrukturering van gesondheidsdienste, wat ten tye van hierdie ondersoek pas afgehandel is, kon moontlik bygedra het tot die onvolledigheid van die gemeenskapsdiagnoses.

\section{Erkenning}

Ons dank en erkenning aan die Raad vir Geesteswetenskaplik Navorsing vir die finansiële steun van hierdie navorsing.

Die navorsers wil die bestuurslede van die Nasionale Genootskap van Gemeenskaps- verpleegkundiges van Suid-Afrika (NGGV), wat as sameroepsters en groepleiers tydens die portuurgroepbesprekings van die standaarde landwyd opgetree het, bedank vir hul entoesiasme, kundigheid en tyd.

Ons opregte dank ook aan al die gemeenskapsverpleegkundiges wat aan die portuurgroepbesprekings deelgeneem het vir hul insette in hierdie verband.

\section{BIBLIOGRAFIE}

Braden, CJ. 1984: The focus and limits of community health nursing. Norwalk: AppletonCentury-Croft

Burgess, W. 1983: Community Health Nursing Practice. Norwalk: Appleton-Century-Croft.

Elkins, CP. 1984: Community health nursing; Fourth edition. New York: McGraw-Hill Book Company.

Leahy, KM, Cobb, MM, Jones, MC. 1982: Community health nursing; Fourth edition. New York: McGraw-Hill Book Company.

Masdon, EJ. 1978: How to write meaningful nursing standards. New York: Wiley \& Sons

Schoolcraft, V. 1984: Nursing in the community. New York: John Wiley \& Sons.

Sullivan, AS. 1984: Directions in community health nursing. Boston: Blackwell Scientific Publications.

Tinkham, LW, Voorhies, EF. 1977: Community health nursing. New York: Appleton-CenturyCroft.

Young, RK. 1982: Community Nursing Workbook. Norwalk: Appleton-Century-Crofts.

\section{Health research in infancy}

A great many overseas studies are being carried out into the role of psychology and health, but research in this field is still in its infancy in SA.

The main focus of a November 1989 seminar on Health Psychology, was to get those in the profession together to find out the state of research and thinking in SA, and to ascertain where research is needed.

\section{Perspectives}

Researchers at HSRC are looking at what type of psychological profile maintains health. Why are some people healthy whilst others with the same lifestyle are prone to illness? What life skills can one learn so as to maintain health? The focus is on the prevention of illness as opposed to cures.

No 1 Military Hospital and Natal University are approaching the problem from the medical side, i.e. looking at patients and studying how their illness has affected them psychologically.

Dr Deon van Zyl of the Pain Clinic in Johannesburg, is currently studying psychoneuroimmunology. This field of study covers the interactions between psychological and immunological processes by attempting to link the nervous, endocrine and immune systems.

Research in this field is particularly relevant to the study of psychological influences in infectious diseases, allergies, cancer and autoimmune disorders.

Dr Van Zyl's report on his findings is due in March 1990.

\section{Discoveries}

People react differently to any given set of circumstances. Dr Van Zyl has shown that their immune systems also react differently to emotionally stressful or humorous situations.
This suggests a link between psychological factors and immunological responses.

These findings have implications for both the preventative and treatment aspects of infectious diseases, allergies, cancers, autoimmune disorders and postoperative healing.

A productive line of study could involve the possible relationships of stress, depression of positive emotions, to the progression and outcome of diagnosed illnesses. One such study found that subjects receiving relaxation training, stress management and an imagery technique reported a significantly greater reduction in recurrent genital herpes activity when compared with the control groups.

HSRC Bulletin April 1990 